\title{
Key bird species of Marojejy Strict Nature Reserve, Madagascar
}

\author{
M. I. EVANS, J. W. DUCKWORTH, A. F. A. HAWKINS, R. J. SAFFORD, \\ B. C. SHELDON and R. J. WILKINSON
}

\section{Summary}

From mid-August to late October 1988, Marojejy Strict Nature Reserve, in the northern part of Madagascar's rainforest, was surveyed for birds. The reserve extends from 75 to $2,133 \mathrm{~m}$ altitude and the 60,150 ha comprise an almost intact series of altitudinal forest zones. Observations were made in all forest zones and at all altitudes of the reserve and the total of 104 species found included almost all Madagascan rainforest birds, making Marojejy one of the most important sites for bird conservation in Madagascar. The status of the eight threatened, 10 near-threatened and two restricted-range species observed is detailed here, together with notes on their ecology and behaviour. Finds of major conservation interest included the first documented sighting of Madagascar Serpent-eagle Eutriorchis astur since 1930, a healthy population of Henst's Goshawk Accipiter henstii, all four rainforest ground-rollers Brachypteraciidae and a new population of Yellow-bellied Sunbird-asity Neodrepanis hypoxantha. Furthermore, the patchy distribution of Helmetbird Euryceros prevostii urges reconsideration of its current assessment as not at risk. Four threatened species (Rufous-headed Ground-roller Atelornis crossleyi, Yellow-bellied Sunbird-asity, Grey-crowned Greenbul Phyllastrephus cinereiceps and Madagascar Yellowbrow Crossleyia xanthophrys) were found only in the upper montane forests; this apparent altitudinal preference for three of these species had not been suggested before this survey. The major threat to the birds of Marojejy is the ceaseless piecemeal clearance of the reserve's forest, which is proceeding inwards from the boundary.

De la mi-août à la fin octobre 1988, une étude sur les oiseaux a été menée dans la Réserve Naturelle Intégrale de Marojejy, située dans le nord de la forêt équatoriale de Madagascar. La réserve s'étend sur une altitude allant de 75 à 2,133 mètres et sa superficie de 60,150 ha abrite une série de forêts d'altitude restées pratiquement intactes. Des observations ont été faites dans toutes les zones forestières et à toutes les altitudes de cette réserve et les 104 espèces d'oiseaux trouvées incluaient presque toutes les espèces d'oiseaux de la forêt tropicale de Madagascar, la réserve de Marojejy représentant ainsi l'un des sites de conservation des oiseaux les plus importants de Madagascar. La situation des huit espèces menacées, dix espèces presque menacées et deux espèces à distribution géographique limitée, observées au cours de l'étude, est décrite ici en détail, avec des notes sur leur écologie et leur comportement.

Parmi les découvertes particulièrement intéressantes pour la conservation, nous pouvons citer la première observation documentée de l'aigle-autour Eutriorchis astur depuis 1930, une population bien développée de Accipiter henstii, l'ensemble des quatre types forestières de Brachypteraciidae et une nouvelle population de Neodrepanis hypoxantha. De plus, la répartition géographique inégale de l'Euryceros prevostii exige une reconsidération urgente de son évaluation actuelle en tant qu'espèce sans risque. Quatre espèces menacées (Atelornis crossleyi, Neodrepanis hypoxantha, Phyllastrephus cinereiceps et Crossleyia xanthophrys) n'ont été trouvées que dans les forêts de haute altitude: 
l'apparente préférence de ces trois espèces pour les hautes altitudes n'avait pas été suggérée avant cette étude. La principale menace pour les oiseaux de Marojejy est le défrichage incessant de la forêt de la réserve, cette destructiơn s'étendant progressivement de l'extérieur vers l'intérieur de la forêt.

\section{Introduction}

Madagascar lost an estimated 111, ooo ha of rainforest every year between 1950 and 1985 (Green and Sussman 1990). Most of the relatively small amount of primary rainforest remaining is in a belt down the eastern edge of the island's spine, especially in the north-east, with outlying areas almost to the southern tip (see Green and Sussman 1990). A large proportion of the unique Malagasy avifauna is regarded as threatened, mainly because of the destruction of the eastern forest (Collar and Stuart 1985); within Madagascar, the Eastern Malagasy region has the highest diversity of resident avifauna, with 42 species endemic to it (Langrand 1990).

The Réserve Naturelle Intégrale (RNI) no. 12 de Marojejy ( $14^{\circ} 18^{\prime}-39^{\prime} \mathrm{S} 49^{\circ} 33^{\prime}-$ $52^{\prime} \mathrm{E}$; Figure 1) is at the northern end of the island's eastern rainforest belt. It is an isolated mountain massif composed of 60,150 ha of mainly pristine forest, at

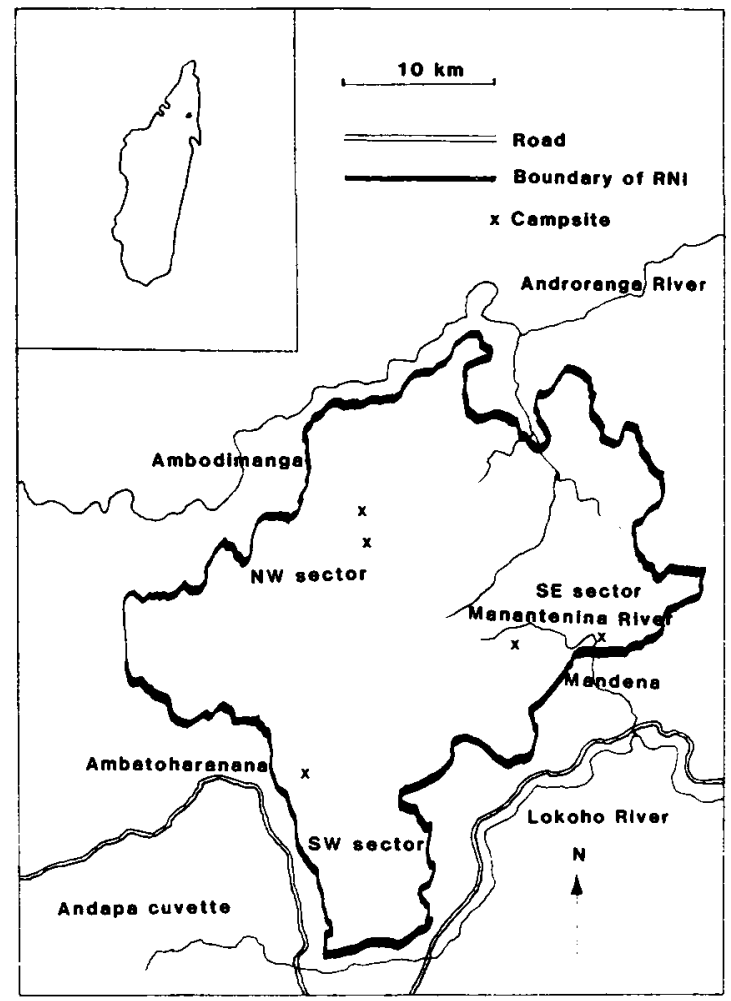

Figure 1. Marojejy Strict Nature Reserve, Madagascar. Inset shows position of Marojejy within Madagascar. 
75 to $2,133 \mathrm{~m}$ altitude; forest clearance has advanced up to at least the southern, western and northern boundaries, meaning that the forests of Marojejy are now fundamentally isolated from similar habitat found to the south and west. Of the five major massifs in Madagascar, Marojejy is the only one to retain largely intact high-altitude vegetation (Guillaumet 1984, Langrand 1990).

Previous work (e.g. Humbert 1955, Guillaumet et al. 1975, Benson et al. 19761977) indicated Marojejy's exceptional floral and faunal diversity, and a number of threatened species were known to occur there. Marojejy was established as a strict nature reserve in 1952, largely because of the vegetational diversity documented by Humbert (1955), and is under the management of the Association Nationale pour la Gestion des Aires Protégées. It is divided into four sectors, each under the control of a forest guard. The RNI designation forbids entry except by research permit from the Direction des Eaux et Forêts (DEF) of the Ministère de la Production Animale (Elevage et Pêche) et des Eaux et Forêts (MPAEF) in Antananarivo.

During 1988 one Malagasy and seven British observers visited Marojejy to survey the area's birds and mammals and investigate the relationship of local human communities with the reserve (Safford and Duckworth 1990, Sheldon and Duckworth 1990, Duckworth in press). Three of the four sectors were visited. The survey period of 18 August to 23 October fell almost entirely within the driest season, which extends into November. Most rainforest passserines in Madagascar probably breed from August to February (see Safford and Duckworth 1990).

\section{Habitats of Marojejy}

Floristically, Marojejy lies within the East Malagasy Regional Centre of Endemism, which ascends from the eastern coast of Madagascar to approximately $800 \mathrm{~m}$ in the central highlands (White 1983). Marojejy is particularly noted for its exceptional diversity of vegetation, associated with its very high rainfall and variety of relief and altitudes (Humbert 1955). The following simplified habitat scheme, compiled from Humbert (1955), Guillaumet et al. (1975), White (1983) and Nicoll and Langrand (1989), divides the forest into five types, largely dependent on altitude. Vegetational zones are typically lower on smaller mountains, rather than being at similar altitudes with the upper zones missing (the Massenerhebung effect: see Whitmore 1984) and this must be borne in mind when altitudes from different massifs are compared.

\section{Primary lowland rainforest (Eastern Domain)}

Often referred to as forêt orientale, this type is restricted to lower-lying valleys in the reserve (Nicoll and Langrand 1989), such as the Manantenina valley, where it is largely degraded. No significant areas of undegraded lowland forest were found.

\section{Secondary lowland forest (Eastern Domain)}

The reserve boundary excludes most secondary vegetation although an area of abandoned cultivation of about $150-250$ ha in the Manantenina valley is now 
dominated by giant bamboo Ochlandra capitata and wild ginger Aframomum angustifolium. Much land adjacent to the reserve, especially to the north, is sparse, barren grassland devoid of any woody species due to intensive burning (Rand 1932, 1936, Safford and Duckworth 1990).

\section{Moist montane forest (Central Domain)}

A gradual transition from lowland rainforest is made into this type (also called forêt à mousses et sous-bois herbacé or mid-altitude rainforest) around $800 \mathrm{~m}$. Most areas surveyed supported this vegetation formation.

\section{Sclerophyllous montane forest (Central Domain)}

The level of maximum rainfall is around $1,450 \mathrm{~m}$ where the cloud is thickest. Above this level, principally at 1,600 to $1,800 \mathrm{~m}$, sclerophyllous montane forest (sylve à lichens) occurs, although distribution is limited as much by edaphic conditions as by climate, so that the boundary is complex (Humbert 1955).

\section{Montane scrub (High Mountain Domain)}

Montane scrub occurs from about $1,850 \mathrm{~m}$ to the summit, Marojejy Est $(2,133 \mathrm{~m})$, and is very heterogeneous in both physiognomy and composition, depending on edaphic conditions.

\section{Field observations: methods and sites}

Birds were recorded almost continually by day using a flexible approach, whereby observers (usually working singly) were free to observe mixed-species flocks and follow up unusual calls rather than keep to a fixed schedule. Observations in all available habitats used both passive and active strategies. A portable tape-recorder with directional microphone helped with skulking species. The dates and altitudes of observation in each sector are given in Table 1.

\section{South-west (SW) sector}

The study area (entered from the village of Ambatoharanana, $18 \mathrm{~km}$ north of Andapa) was dominated by a north-south ridge parallel to and about $1 \mathrm{~km}$ east of the reserve boundary, with a very steep slope down to the Andapa cuvette to the west, and more undulating forested country with frequent ridges to the east.

Primary forest did not extend beyond the reserve boundary; it was continuous within it, though clearly disturbed. Evidence of current hunting and collection of plant resources was widespread. The very large trees in the degraded forest on the lowest slopes of the reserve were typical of primary lowland rainforest, but most vegetation within was moist montane forest. On ridges, the forest had a lower canopy (as low as $15 \mathrm{~m}$, compared to the 20-25 $\mathrm{m}$ typical elsewhere). Sheltered depressions and river valleys were left very dark and damp by the closed canopy, with a shrub layer of spindly saplings, and little or no herb-layer. 
North-west (NW) sector

(a) Low site An area with a radius of $2 \mathrm{~km}, 4 \mathrm{~km}$ inside the reserve boundary in the Antsahaberoakahely river valley, was explored. Incidental observations were made between the camp ( $800 \mathrm{~m}$ ) and the village of Ambodimanga (450 $\mathrm{m}$ ). The study area was largely enclosed by the valley in steeply undulating country, with occasional rocky outcrops. The river allowed excellent views over a large area of sky and canopy.

This area was undisturbed primary forest. Most vegetation appeared to be typical moist montane forest, with a $20-30 \mathrm{~m}$ canopy, and a tree density similar to that found in the SW sector. One sheltered patch at $800 \mathrm{~m}$ seemed similar to lowland rainforest, with many $40 \mathrm{~m}$ high trees; large patches of understorey were dominated by Melastomataceae.

(b) High site A further $5 \mathrm{~km}$ into the reserve, at $1,300 \mathrm{~m}$, the forest in valleys still looked similar to moist montane forest at $800 \mathrm{~m}$, with large trees $(25-35 \mathrm{~m}$ canopy) and an open understorey. Ridges supported sclerophyllous montane forest, and there was a small area of montane scrub on an isolated $1,400 \mathrm{~m}$ summit.

\section{South-east (SE) sector}

(a) Low site The Manantenina valley $3 \mathrm{~km}$ inside the reserve was largely covered with degraded lowland rainforest with a thick understorey and tangles of lianes and occasional very large trees; along the river the forest had been cleared for coffee cultivation before the reserve was created, but was now overgrown with Aframomum angustifolium and Ochlandra capitata. Many forms of disturbance occur in this sector near the villages, but are now kept to a minimum by the forest guard. Further up the valley sides, where slopes became very steep, the primary forest was pristine. Along the river, open sky and canopy could be viewed.

(b) High sites Above $500 \mathrm{~m}$ altitude in the valley, the forest appeared intact, marking the upper limit of the previously cultivated area as well as of regular current disturbance. Single nights were spent at $700 \mathrm{~m}$ (incidental observations only) en route for a site at 1,300 $\mathrm{m}$ on the interface of moist and sclerophyllous montane forests, the former (canopy up to $25 \mathrm{~m} ; 30 \mathrm{~m}$ in the most sheltered dells) being general on the slopes, the latter (canopy 7-12 $\mathrm{m}$ ) dominating on the ridges; the two intergraded between 1,200 and 1,500 $\mathrm{m}$. The moist montane forest was lower in stature and with a denser understorey than at the same altitude in the NW sector, although overall tree densities seemed similar to those in the NW. Sclerophyllous montane forest was dominant from 1,500 to 1,800 m, becoming stunted before giving way to montane scrub. These two most fragile and rare of Malagasy plant communities appeared intact with a small series of marshes and pools at $2,050 \mathrm{~m}$ west of the summit.

As the forest became more stunted, it was easier to view the canopy and sky; landslips also provided convenient clearings. However, the forests higher up 
were impenetrable; exploration was restricted to within $200 \mathrm{~m}$ of the one path. Because of bad weather, the montane scrub was only visited twice, totalling six observer-days.

\section{Important bird species found in Marojejy}

Bird communities in relation to habitat, especially altitude and degradation, are discussed in Safford et al. (in prep.). The species discussed here are those treated as threatened (eight) or near-threatened (ten) by Collar and Stuart (1985), and also Red-breasted Coua Coua serriana and Helmetbird Euryceros prevostii, which on current knowledge are restricted to the northern half of the eastern forest and are thus considered "particularly vulnerable" by Langrand (1990). All are endemic to Madagascar's eastern rainforest belt. Table 1 shows the status of these species in Marojejy. Where no section is included for breeding, no indications were observed. Nomenclature follows Collar and Stuart (1985).

Madagascar Crested Ibis Lophotibis cristata

Near-threatened

Nationwide status Widely distributed in eastern and western forest, it seems adaptable to secondary forest but is everywhere hunted (Dee 1986). Numbers are declining everywhere because of intensive trapping (Langrand 1990).

Status in Marojejy The lack of records in the SW sector may indicate hunting pressures in this area (see discussion). This species survived in degraded forest in the SE sector but was largely restricted to areas below 1,000 $\mathrm{m}$ (only one was recorded above this) and is under special threat from hunting, given its relatively large size and presumed low productivity. Some birds in Marojejy were particularly approachable, perhaps indicating a lack of current hunting but suggesting their potential vulnerability.

Behaviour Birds fed in two fashions. Usually they probed deep into forest soil and thick leaf-litter with jerky vertical or forward stabs of the bill, rooting vigorously at different angles to extract prey items when found; this took place in waterlogged streamside soils, valley sides and dry ridge-tops. Paths were sometimes followed. They also walked through streams picking up small items. When disturbed, reactions included freezing, walking or running out of sight and flying up into trees or through the canopy; sometimes the birds were surprisingly confiding, allowing observers to watch them feeding $10 \mathrm{~m}$ away. They were usually in twos, though often individuals could be quite widely separated, and twos were often split by observers. A presumed alarm note was given when one was disturbed by an observer but did not fly off: a quiet, drawnout creaking, like one tree rubbing against another.

Madagascar Baza Aviceda madagascariensis

Near-threatened

Nationwide status Everywhere scarce, but recorded from a wide range of sites and habitats (Dee 1986) and considered fairly common in the east by Langrand (1990).

Status in Marojejy The four records came from a variety of habitats, including 
Table 1. Observations of important bird species in Marojejy. Species records are detailed by sector. For each sector, the altitudes where the bird was recorded are given, followed by the minimum to maximum daily counts (excluding days when the species was not recorded), with the number of days the species was observed in parentheses.

\begin{tabular}{|c|c|c|c|}
\hline & $\begin{array}{l}\text { South-west } \\
\text { sector }\end{array}$ & $\begin{array}{l}\text { North-west } \\
\text { sector }\end{array}$ & $\begin{array}{l}\text { South-east } \\
\text { sector }\end{array}$ \\
\hline \multicolumn{4}{|l|}{ Observation details } \\
\hline Observation dates & 18 Aug-5 Sep & $\begin{array}{l}\text { 9-26 Sep; } \\
22-26 \text { Sep }\end{array}$ & $\begin{array}{l}7-15 \text { Oct; } \\
16-23 \text { Oct }\end{array}$ \\
\hline Altitudes covered & $600-900 \mathrm{~m}$ & $\begin{array}{c}700-900 \mathrm{~m} \\
1,300-1,400 \mathrm{~m}\end{array}$ & $\begin{array}{c}200-400 \mathrm{~m} \\
1,200-2,133 \mathrm{~m}\end{array}$ \\
\hline \multicolumn{4}{|l|}{ Bird records } \\
\hline Madagascar Crested Ibis & - & $\begin{array}{c}500-900 \mathrm{~m} \\
2-6(6)\end{array}$ & $\begin{array}{c}200-1,300 \mathrm{~m} ; \\
\mathrm{I}-2(4)\end{array}$ \\
\hline Madagascar Baza & $800 \mathrm{~m} ; 1(1)$ & $\begin{array}{l}1,400 \mathrm{~m} \\
\quad 1(1)\end{array}$ & $\begin{array}{c}300-1,300 \mathrm{~m} ; \\
1(2)\end{array}$ \\
\hline Madagascar Serpent-eagle & - & $\begin{array}{l}850 \mathrm{~m} ; \\
1(1)\end{array}$ & - \\
\hline Henst's Goshawk & $\begin{array}{c}600-900 \mathrm{~m} ; \\
1-2(5)\end{array}$ & $\begin{array}{c}500-1,000 \mathrm{~m} \\
1-2(10)\end{array}$ & $\begin{array}{l}300 \mathrm{~m} ; \\
1-2(4)\end{array}$ \\
\hline Banded Kestrel & $800 \mathrm{~m} ; 1(3)$ & - & - \\
\hline Brown Mesite & - & $\begin{array}{l}700 \mathrm{~m} ; \\
\quad 1(1)\end{array}$ & - \\
\hline Red-breasted Coua & $\begin{array}{c}500-800 \mathrm{~m} ; \\
1(4)\end{array}$ & $\begin{array}{l}800 \mathrm{~m} ; \\
\mathrm{I}-7(10)\end{array}$ & $\begin{array}{c}300 \mathrm{~m} \\
2-13(8)\end{array}$ \\
\hline Short-legged Ground-roller & $\begin{array}{l}800 \mathrm{~m} ; \\
\mathrm{I}-2(2)\end{array}$ & $\begin{array}{l}800 \mathrm{~m} ; \\
1-4(8)\end{array}$ & $\begin{array}{c}300-600 \mathrm{~m} \\
1-5(5)\end{array}$ \\
\hline Scaly Ground-roller & $\begin{array}{l}800 \mathrm{~m} ; \\
2(1)\end{array}$ & $\begin{array}{l}800 \mathrm{~m} ; \\
1(4)\end{array}$ & $-\ldots$ \\
\hline Pitta-like Ground-roller & $\begin{array}{l}800 \mathrm{~m} ; \\
1-3(2)\end{array}$ & $\begin{array}{l}800 \mathrm{~m} ; \\
1-3(6)\end{array}$ & - \\
\hline Rufous-headed Ground-roller & & $\begin{array}{c}1,300 \mathrm{~m} \\
2-5(3)\end{array}$ & - \\
\hline Yellow-bellied Sunbird-asity & - & - & $\begin{array}{c}1,500-1,700 \mathrm{~m} \\
1-3(3)\end{array}$ \\
\hline Grey-crowned Greenbul & - & $\begin{array}{l}1,300 \mathrm{~m} \\
3-19(5)\end{array}$ & $\begin{array}{c}1,300-1,500 \mathrm{~m} \\
1-14(4)\end{array}$ \\
\hline Bernier's Vanga & $\begin{array}{c}600-900 \mathrm{~m} ; \\
1-6(10)\end{array}$ & - & - \\
\hline Helmetbird & $\begin{array}{c}600-900 \mathrm{~m} ; \\
1-5(8)\end{array}$ & $\begin{array}{c}800 \mathrm{~m} ; \\
1(1)\end{array}$ & $\begin{array}{l}300 \mathrm{~m} ; \\
1-2(7)\end{array}$ \\
\hline Wedge-tailed Jery & - & $\begin{array}{c}800-1,300 \mathrm{~m} \\
1-5(6)\end{array}$ & - \\
\hline Madagascar Yellowbrow & - & $\begin{array}{l}1,300 \mathrm{~m} \\
2-18(5)\end{array}$ & $\begin{array}{c}1,200-1,400 \mathrm{~m} \\
4-9(8)\end{array}$ \\
\hline Brown Emu-tail & - & $\begin{array}{c}800-1,300 \mathrm{~m} \\
1-3(8)\end{array}$ & $\begin{array}{c}1,300-2,000 \mathrm{~m} \\
1-10(8)\end{array}$ \\
\hline Rand's Warbler & $\begin{array}{l}600-900 \mathrm{~m} ; \\
\mathrm{I}-4(17)\end{array}$ & $\begin{array}{c}800-1,300 \mathrm{~m} \\
1-10(7)\end{array}$ & - \\
\hline Ward's Flycatcher & $\begin{array}{c}600-900 \mathrm{~m} \\
1-3(4)\end{array}$ & $\begin{array}{c}800-1,300 \mathrm{~m} \\
1-9(16)\end{array}$ & $\begin{array}{c}1,200-1,700 \mathrm{~m} \\
1-3(5)\end{array}$ \\
\hline
\end{tabular}


degraded forest in the SE sector. As the species is inactive, possibly crepuscular (Rand 1936), spending much time perched below the canopy and looking remarkably similar to Madagascar Buzzard Buteo brachypterus, it may have been under-recorded.

Behaviour An aerial display took place high above the canopy at 1 ohoo on 23 September: several times the bird flew straight, then tilted sideways and simultaneously fluttered its wings. One (probably the same) performed vertical stoops from high above the forest later the same day. The related African Cuckoo-falcon $A$. cuculoides also has an aerobatic display with much sideways banking and diving (Brown et al. 1982). One appeared to be roosting (it had its eyes shut) before being flushed from a tree at 14 hoo. When gliding, one used its tail as a rudder, like a kite Milvus.

Nationwide status Known from 12 specimens collected in the centre-east and north-east of the island between 1874 and 1930 (Collar and Stuart 1985, N. J. Collar verbally 1989, I. J. Ferguson-Lees in litt. 1990). A forest guard reported several sightings of this species at Marojejy between 1964 and 1977 (Collar and Stuart 1985). In 1990, a dead one was found in Ambatovaky Special Reserve (Raxworthy and Colston 1992).

Status in Marojejy An individual in moist montane forest represented the first confirmation of this species's existence since 1930. The lack of records for $5^{8}$ years may be due to a combination of very low density (see Thiollay [1989] for a discussion of densities of tropical rainforest raptors), identification difficulties and elusive habits. Extensive notes were made of this individual at very close range over 25 minutes; the superficially similar Henst's Goshawk was eliminated on 10 plumage and structural differences (Sheldon and Duckworth 1990).

\section{Henst's Goshawk Accipiter henstii}

Near-threatened

Nationwide status Widely recorded in a variety of wooded habitats, including secondary forest, but always regarded as scarce (Dee 1986) or even rare (Langrand and Meyburg 1984, Langrand 1990).

Status in Marojejy The species was usually seen above primary forest, although outside the reserve three singles were seen along the western and northern forest edge. Benson et al. (1976) found it nesting in a Eucalyptus plantation near Périnet. Birds were rarely visible from below the canopy and hence probably under-recorded. However, none was seen from the NW sector campsite, which had a wide view of open sky. Detection was aided by the birds' regular calling, and this should be considered when comparing these numbers with records from other seasons; loud calling has also been heard in eastern rainforest in March (M.I.E. pers. obs.).

Behaviour Several were seen soaring (contra Langrand 1990) and calling (a loud series of up to 20 downwardly inflected "koh" calls at $0.5^{-1}$ second intervals) during September and October, and one performed a "switchbacking" display 
like a Northern Goshawk A. gentilis (see Cramp and Simmons 1980) on 2 September.

Banded Kestrel Falco zoniventris

Near-threatened

Nationwide status Recorded from a wide variety of habitats and sites (forest and degraded zones) from sea level to $1,000 \mathrm{~m}$ (Rand 1936) but generally considered rare (Dee 1986, Langrand 1990).

Status in Marojejy As well as three in the reserve, there were singles in coffee and vanilla plantations and brush near Antanimabaribe (adjacent to SW sector, $400 \mathrm{~m}$ ) and in forest west of the reserve's SE sector (900 m). Benson et al. (1976) found it common in brush in the Manantenina valley (next to the SE sector). This species undoubtedly occurs in areas of degraded habitat, but may be limited to such sites near good forest and lowland areas. Its habit of perching high in trees for long periods (noted also by Rand 1936) makes it very difficult to detect from under the canopy. Despite wide distribution and catholic habitat choice, this species is very patchily distributed and little is known of its biology (Cade 1982). An investigation of adaptability to anthropogenic habitat change would be very interesting and Marojejy, where it occurs in primary and adjacent degraded zones, would seem a very good site to pursue this.

Behaviour All five birds seen were perched on isolated high tree-tops. One individual, perched immobile atop a dead tree at the edge of a clearing, plummeted downwards to pounce on a prey item on a large trunk, then sped into the forest, soon to reappear on the dead tree. Colebrook-Robjent (1973) described similar behaviour to catch chameleons.

Brown Mesite Mesitornis unicolor

Insufficiently known

Nationwide status Rarely recorded throughout the eastern rainforest (Collar and Stuart 1985, Langrand 1990).

Status in Marojejy Mesites are skulking and elusive; as we did not know this species's call, it may have been commoner than the one record from pristine moist montane forest may suggest. However, R.J.S. subsequently found the species easily on the Masoala peninsula when silent, and considers it unlikely that it was common in Marojejy during this survey. It was heard in the SE sector in 1987 (O. Langrand and L. Wilmé verbally 1988).

Behaviour The bird was observed foraging silently and alone from 16 h15 to 16h45; when flushed it fluttered and ran a short distance before resuming foraging as it walked away. It chased small invertebrates across the leaf-litter, or gleaned from leaves and stems at ground level. The forest floor was very open, lacking a herb-layer, with a thick covering of dead leaves, its favoured habitat (Langrand 1990, R.J.S. from observations at Masoala).

\section{Red-breasted Coua Coua serriana}

Nationwide status Fairly common from sea level to $1,000 \mathrm{~m}$ in the northern half 
of the eastern rainforest (Rand 1936, Dee 1986, Langrand 1990) south to Périnet (Quansah 1988, Safford and Duckworth 1990).

Status in Marojejy This species seemed to be very unevenly distributed and was nowhere found above $800 \mathrm{~m}$. It was common in degraded forest in the SE sector around $300 \mathrm{~m}$ and in some pristine forest in the NW sector at $800 \mathrm{~m}$ (where it seemed to prefer areas with a dense herb layer of Melostomataceae), but elsewhere it was rare. One was seen in thick secondary brush outside the reserve's northern boundary; this, combined with its abundance in the degraded forest of the SE sector, shows that it must adapt to habitat degradation, but it seems to be geographically and altitudinally restricted (Rand [1936] likewise did not find it above $1,000 \mathrm{~m}$ ) and is presumably hunted, like all large terrestrial birds.

Behaviour All feeding seemed to take place on the ground, often in areas with a dense herb-layer. The only food item noted was a silk-wrapped bundle in a spider's web; the species is said to be more frugivorous than Reynaud's Coua $C$. reynaudii (Rand 1936).

Nationwide status Found throughout the eastern rainforest belt, in most areas of primary forest recently surveyed (Collar and Stuart 1985, N. J. Collar verbally 1989). Langrand (1990) considered it secretive and rather rare.

Status in Marojejy This species was found only in primary forest and was only common in the most undisturbed areas. It was absent from degraded lowland rainforest at $300 \mathrm{~m}$ in SE sector (though found daily in nearby pristine forest) and rare in disturbed forest in the SW sector. Rand (1936: 189) took specimens from $1,800 \mathrm{~m}$, one day west of Andapa; his description of the habitat at this site sounds like that found at around 1,300 $\mathrm{m}$ at Marojejy, but the species was not found above $800 \mathrm{~m}$ at Marojejy. There was little fieldwork between 900 and $1,300 \mathrm{~m}$ at Marojejy, but given the species's conspicuousness at $300-600 \mathrm{~m}$ in the SE sector it is unlikely that it was missed at $1,300-1,800 \mathrm{~m}$ in that sector. However, it could have been overlooked at 1,300 $\mathrm{m}$ in the $\mathrm{NW}$ sector, where fieldwork took place before calling started. The total of 27 records, all from lowland rainforest or lower-altitude moist montane forest, must indicate a preference for lower altitudes.

Behaviour A probable nest hole was found in the NW sector at $800 \mathrm{~m}$ on 11 September. A bird flew down to the base of a small earth bank, $1 \mathrm{~m}$ from a stream, and later investigation revealed a flattened oval entrance hole $10 \mathrm{~cm}$ across, with fresh scratch marks around the entrance; the bird had worn tailfeather tips. If breeding was in progress it is odd that no display was noted since this was so conspicuous in the SE sector.

Birds were displaying in the SE sector from 9 October. Display was delivered from a higher perch than normal, often $20 \mathrm{~m}$ up. It consisted of a single deep, hollow, far-carrying "boop" or "whop" call (confusable with a frog or owl), uttered while the head was bobbed downwards; sometimes this was preceded by flicking out the wings and tail. On one occasion this was performed with another bird $1 \mathrm{~m}$ away on the same branch: one or other bird made a very quiet, 
deep churring note in-between each "boop". The displaying bird regularly flew from perch to perch, followed after a few seconds on each occasion by the other bird. One bird called from several different perches in an area about $50 \mathrm{~m}$ by $50 \mathrm{~m}$.

In a total of about 15 hours' observation at all times of day birds were rarely seen to feed. They spent most time perched motionless up to $10 \mathrm{~m}$ above the forest floor, in trees, pandans or shrubs, occasionally flying fast and straight from perch to perch, this in keeping with Turner's (1984) and Langrand's (1990) judgement of the species as the least terrestrial ground-roller. However, the first sighting of a bird was often when it was flushed from on or near the ground up into a tree, typically in areas of well-developed shrub-layer but little herb-layer. Prey items (all terrestrial) noted were several insects, including one $3 \mathrm{~cm}$ beetle and a $10 \mathrm{~cm}$ frog (possibly Boophis albilabris), which the bird darted $7 \mathrm{~m}$ from its perch on a liane to catch (unsuccessfully).

Scaly Ground-roller Brachypteracias squamiger

Rare

Nationwide status Known mainly from the north of the rainforest belt, especially the Masoala Peninsula and Maroantsetra (Collar and Stuart 1985); rather rare throughout its range (Langrand 1990).

Status in Marojejy All five records came from lower-altitude moist montane forest, at the same sites as Short-legged and Pitta-like Ground-rollers. The three sites where they were seen all shared extremely tangled undergrowth, as noted by Langrand (1990) and R.J.S. on Masoala, in contrast to Brown Mesite; the birds seemed to prefer to escape by running through this rather than flying.

Behaviour Two were together on 30 August, but no interaction between them was seen. A gravid female was shot and a nest found in September 1972 in the SE sector (Benson et al. 1976: 236). The birds stood motionless before running a few steps to catch prey by turning over leaves, rummaging in thick leaf-litter or investigating logs; one also pulled up worms from the forest floor. All actions were rather like a thrush Turdus.

Pitta-like Ground-roller Atelornis pittoides

Near-threatened

Nationwide status The most widely distributed ground-roller, known from all rainforest areas up to 1,800 $\mathrm{m}$ (Rand 1936, Dee 1986, Langrand 1990); occurs in degraded primary and even secondary forest at Ranomafana (Safford and Duckworth 1990).

Status in Marojejy Like Short-legged Ground-roller, all records were from below 1,000 m; all were in moist montane forest. The lack of sightings in the SE sector may indicate a patchy distribution.

Behaviour Two were seen together on 17 September, when quiet clucking notes seemed to serve in keeping contact; otherwise all were single. Birds were seen to take small terrestrial invertebrates while walking slowly along the ground or over dead branches and trees. They were entirely terrestrial, even occurring in areas of dense herb-layer, contra Langrand (1990). 
Nationwide status Considered the rarest and least-known ground-roller (Turner 1984), but specimens are known from scattered sites in the east (Collar and Stuart 1985). Fairly rare throughout its range (Langrand 1990).

Status in Marojejy This was the only ground-roller found at high altitude, if only in the NW sector, where it was common in the small area surveyed. Much more effort was spent by us in the SE sector above 1,300 $\mathrm{m}$ than in the NW, but this species was not found. However, Griveaud (1960) took a specimen at $1,600 \mathrm{~m}$ in sclerophyllous montane forest in the SE sector.

Behaviour One pair frequented the camp, feeding tamely within a few feet of us. One (presumed male) displayed regularly, most often at dawn and dusk but also at other times. The display was delivered from a horizontal branch about $30 \mathrm{~cm}$ off the ground; the bird gave a deep "whoop" or "doo-hu", with an almost inaudible second syllable, and a simultaneous downward head-bob and upward tail-flick. This calling attracted a presumed female (seemingly identical in plumage), which croaked quietly as it approached, but no further developments ensued. Another (contact?) call was a very quiet clucking or popping "bok", frequently uttered. A likely nest hole at the bottom of an overhanging sandy bank was about $15-20 \mathrm{~cm}$ across, at least $30 \mathrm{~cm}$ long, curving down and then up again under a rock. In $1.5 \mathrm{hrs}$ watching one adult peered inside once; the hole had bird footprints all around it. They always fed on the ground, on small invertebrates including a moth, beetle larvae and a $6 \mathrm{~cm}$ millipede.

\section{Yellow-bellied Sunbird-asity Neodrepanis hypoxantha}

Indeterminate

Nationwide status Thirteen specimens were collected up to 1929, from the centre-east highland region (Collar and Stuart 1985, Dee 1986). Recent records are discussed in Hawkins et al. (in prep.).

Status in Marojejy This species was found in an extremely narrow altitude range in sclerophyllous montane forest, a rare and very threatened habitat (Guillaumet 1984, M. E. Nicoll and O. Langrand verbally 1988). It was the only species seen only in this habitat, but even here seemed to be very local, as after the first sighting (a single) six observer-days were spent in the area without success, until four birds were found at a slightly lower site. If this is indeed the only habitat, and if the densities found at Marojejy are typical, then this must be one of the numerically rarest and most threatened of all Madagascar birds (Hawkins et al. in prep.)

Nationwide status Specimens are known from a few scattered rainforest sites (Collar and Stuart 1985), but there are few records since 1930; Langrand (1990) considered it common at only one of five sites.

Status in Marojejy This species was commonest in moist montane forest at $1,300 \mathrm{~m}$ in the NW sector and elsewhere was only found in moist and sclerophyllous montane forest in the SE sector; it was the commonest greenbul 
in these habitats, usually first noticed by its unremarkable "tsip" call, similar to a Short-billed Greenbul $P$. zosterops. It also used a trill, again similar to Short-billed Greenbul. The narrow altitudinal range and threatened habitat occupied by this species must limit its population size and partly explain its little-known status; Madagascar Yellowbrow was likewise a locally common species at the same restricted altitudes.

Behaviour Most fed in mixed-species flocks, although in the SE sector singlespecies groups also occurred. Rand (1936) described it as a "bird of ground cover in heavy forest, gleaning for insects through low bushes". Those seen at Marojejy did not feed in this manner, however, and were in forest which was low in stature and generally not seemingly "heavy". Usually they hopped steadily up trunks $2 \mathrm{~cm}-1 \mathrm{~m}$ in diameter, from 0.5 to $15 \mathrm{~m}$ up, like a woodpecker Picidae, and without the stop-start, spiralling progress of a Coral-billed Nuthatch-vanga Hypositta corallirostris. They also fed among twigs and occasionally leaves. One inserted its head in a hole in the ground. Other greenbuls, especially Long-billed $P$. madagascariensis, fed on trunks but not as persistently. Langrand (1990) and Thompson and Evans (1992, this issue) also found them foraging on trunks.

\section{Bernier's Vanga Oriolia bernieri}

Near-threatened

Nationwide status Found widely in the northern half of the rainforest belt between sea level and 1,000 $\mathrm{m}$ (Rand 1936). Status previously considered as Indeterminate in King (1978-1979).

Status in Marojejy This species was remarkably localized: although fairly common in the SW sector, where it outnumbered Helmetbird, it was found nowhere else. Birds were generally noisy and conspicuous and hence not easily overlooked. Langrand (1990) mentions a preference for forest with pandans Pandanus; these were indeed commonest in the SE sector, though the vangas were not seen to use them directly in Marojejy. Their use of large trees may restrict them to lower altitudes.

Behaviour Nearly all were in mixed-species flocks containing other large vangas, especially White-headed Leptopterus viridis, Tylas Tylas eduardi and Helmetbird. They frequented the largest trunks, using their wedge-like bills to tear or lever off slabs of bark and moss to reveal prey underneath; the noise from falling debris could be striking.

\section{Helmetbird Euryceros prevostii}

Nationwide status Recorded from the north-eastern rainforest, mostly around Maroantsetra and Andapa (Dee 1986), exceptionally south to Périnet (Langrand 1990). Although not treated as threatened by Collar and Stuart (1985), it has one of the most restricted ranges of all vangas and inhabits the most threatened vegetation zones; Langrand (1990) regarded this and the previous species as the two most threatened eastern vangas.

Status in Marojejy This species was common in the SW and SE sectors below 
$900 \mathrm{~m}$; likewise Griveaud (1960) found it at Marojejy between 80 and $900 \mathrm{~m}$. In the SE sector birds were seen in degraded primary forest with a thick understorey and a low canopy but with occasional very large trees, showing it not to be restricted to pristine forest, contra Dee (1986) and Langrand (1990), although birds may be present in degraded areas only when they abut primary forest (as here). Furthermore, it seemed to be confined to lower altitudes. Only one was seen in the NW sector but the species was well known to locals in that region.

Behaviour All but two of those in the SW sector (18 August to 5 September) were in mixed flocks, with no indication of breeding. In the SE sector $(7-23$ October) few such flocks were seen and all Helmetbirds were single; on 7 October one flew around the understorey, watching the observers as if agitated. Helmetbirds usually fed 3-10 $\mathrm{m}$ up, in the understorey and below the canopy, remaining motionless before sallying after large terrestrial or flying insects; one also unsuccessfully chased a Crested Drongo Dicrurus forficatus which was carrying a Brookesia chameleon.

Wedge-tailed Jery Hartertula flavoviridis

Near-threatened

Nationwide status Generally regarded as local and uncommon but widely recorded in the east from 500 to 2,300 $\mathrm{m}$ (Dee 1986, Langrand 1990).

Status in Marojejy This species was commonest in moist montane forest $(1,300 \mathrm{~m})$ in the NW sector; at $800 \mathrm{~m}$ it was rarer, occurring mostly in dense shrub and herb layer below $40 \mathrm{~m}$ trees. Its very patchy distribution lacked obvious reason; the species is easy to identify and, while unobtrusive, unlikely to be overlooked if at all common.

Behaviour One sang on 19 September: a high-pitched, quiet, tinkling warble. This species fed mostly $1-5 \mathrm{~m}$ up in the shrub-layer, or close to the ground in the herb-layer; prey items included a spider. One hovered around bunches of leaves at the ends of branches; others caught small invertebrates by hovering, gleaning or sally-gleaning. Most were in mixed-species flocks, often accompanying greenbuls.

Madagascar Yellowbrow Crossleyia xanthophrys

Indeterminate

Nationwide status Specimens are known from numerous eastern localities but there are few records since 1930 (Collar and Stuart 1985) and Langrand (1990) considered it fairly rare.

Status in Marojejy This was one of the commonest birds of the high-altitude moist montane forest and in lower-altitude sclerophyllous montane forest; the altitudinally limited distribution matched closely that of Grey-crowned Greenbul.

Behaviour Yellowbrows always fed in the leaf-litter or on branches less than $1 \mathrm{~m}$ above it, hopping rapidly and inconspicuously, their dense habitat hampering observations. At dusk they ascend trees to $3 \mathrm{~m}$, presumably to roost. Almost all sightings were of two, usually within 1-2 m of each other; in a group of three on 
16 October one was noticeably dull and pale, and was perhaps a juvenile. They kept in contact by dry, cutting, incisive calls variously transcribed as "tsip", "tsiet" or "tsoip", uttered one to four times per minute. Disyllabic calls ("sersit") were occasionally given. A possible song, an accelerating series of "tsip" notes, was twice heard. A probable alarm note was a quiet grasshopper-like "shrrrrr". They were not particularly shy, probably relying on speed and silence of movement and tendency to forage under the dense herb-layer to avoid predation; imitation of the warning call by hissing with the tip of the tongue invariably attracted birds to the observer immediately, where they perched as close as $1 \mathrm{~m}$ away, agitatedly calling, coming out into the open and ascending small branches to $1 \mathrm{~m}$ above the ground. The species's terrestrial habits did not resemble those of the arboreal Grey-crowned Greenbul (contra Rand 1932). In fact its behaviour was quite unlike any Malagasy greenbul.

Nationwide status Found throughout the eastern rainforest but generally regarded as uncommon and easily overlooked (Dee 1986), though considered fairly common by Langrand (1990).

Status in Marojejy This species was found rarely in moist montane forest at $800 \mathrm{~m}$; at higher altitudes, especially in sclerophyllous montane forest, song was heard commonly but the singer was very hard to see. It was heard in the densest montane scrub; Grey Emu-tail D. seebohmi may occur in such ericoid heath vegetation (Lavauden 1937), but usually prefers marshes (O. Langrand verbally 1988).

Behaviour Much singing was heard from 16 October, the day the montane forests of the SE sector were reached. At $800 \mathrm{~m}$ in the NW sector birds fed in streamside Aframomum and dense herb-layer below $40 \mathrm{~m}$ trees; in montane forest and scrub they occurred in all areas of dense ground flora, always on or close to the ground. The soft trilling "prrrt" call was the principal means of finding them; they often responded to hissing noises made by observers by approaching and mobbing.

Nationwide status Found throughout the eastern rainforest and formerly considered rare (Rand 1936); it has been recorded frequently in recently studied areas up to 1,500 $\mathrm{m}$ (Dee 1986, Langrand 1990).

Status in Marojejy This species was patchily distributed: it was not found in the SE sector in seemingly similar habitats to those in which it was common in the NW sector, and was much commoner at $800 \mathrm{~m}$ in the SW sector than in the NW.

Behaviour One on 18 August was collecting fine strands of moss and lichen, presumably nesting material. Nothing is known of the breeding of this species (Langrand 1990). Most fed in the canopy in mixed-species flocks, pecking at moss and epiphytes on boughs, or searching the bark itself, especially on the 
underside of large horizontal branches, which were examined from the upper side of the bough in characteristic fashion.

\section{Ward's Flycatcher Pseudobias wardi}

Near-threatened

Nationwide status Like Rand's Warbler, recorded patchily for the length of the rainforest belt but formerly considered rare, although commoner at high altitudes (Rand 1936, Dee 1986, Langrand 1990).

Status in Marojejy This species was widely but unevenly distributed: although often common it was not found in degraded lowland rainforest in the SE sector and seemed rare in disturbed moist montane forest in the SW sector, suggesting intolerance of degraded habitat, as suggested by Langrand (1990).

Behaviour Song was heard on 16 October $(1,300 \mathrm{~m})$ and one was collecting nest material on 21 October $(1,600 \mathrm{~m})$. This species fed mostly by sallying out from the canopy, in typical flycatcher fashion.

\section{Discussion}

The total of 104 species identified in and immediately around the reserve is, on current knowledge, an exceptional diversity, including almost all Madagascar rainforest species (Safford et al. in prep.). Eight threatened and nine nearthreatened species were found. Thus of the 13 threatened Madagascar rainforest birds, only five were not found. Of these five, the Snail-eating Coua Coua delalandei was last recorded about $\mathbf{1 8 4 0}$ and is usually considered extinct; the Madagascar Red Owl Tyto soumagnei has only been recorded once since 1934 (Collar and Stuart 1985; J. I. Pollock pers. comm. 1989); the Red-tailed Newtonia Newtonia fanovanae is known only from the type-specimen and two recently discovered populations (Evans 1991, Goodman and Schulenberg 1991); the Dusky Greenbul Phyllastrephus tenebrosa is perhaps another species which, like Grey-crowned Greenbul and Madagascar Yellowbrow, has specific habitat requirements and may occur commonly in certain areas only; and Pollen's Vanga Xenopirostris polleni was seen in a mixed-species flock in September 1972 in forest above Mandena (SE sector). Although this last sight-record is only treated as probable in Benson et al. (1976-1977: 61-62), the description leaves no doubt, mentioning the heavy bluish bill and white underparts; it was accepted by Langrand (1990), who implies that in all plumages Pollen's Vanga has pink underparts (as does Tylas Vanga Tylas eduardi), although three of six Pollen's Vanga specimens in the British Museum (Natural History) have white underparts.

The lower-lying areas of the reserve had the richest threatened avifauna ( 16 of the 20 species considered here), including the first Madagascar Serpent-eagle seen by ornithologists since 1930. The montane forests held four threatened species not found lower down (Rufous-headed Ground-roller, Yellow-bellied Sunbird-asity, Grey-crowned Greenbul and Madagascar Yellowbrow) and were the stronghold of the near-threatened Brown Emutail. Yellow-bellied Sunbirdasity was found sparsely only in the highest-altitude forests, between 1,500 and $1,700 \mathrm{~m}$, a very rare habitat in Madagascar. The apparent preference for highaltitude forests by three of these five species had not been suggested before this 
survey, and emphasizes the need for conserving these forests. Sclerophyllous montane forests are very susceptible to fire, which can easily spread through the thick layer of humus after a period of drought (Humbert 1955, White 1983), although intentional clearance for agriculture is unlikely as these areas are remote from present settlements and the climate is hostile. Montane scrub is even rarer and more fragile, extremely vulnerable to fire, and Marojejy is the only site in Madagascar to retain large areas of it (Guillaumet 1984).

Comparison with other well-studied sites in Madagascar powerfully demonstrates Marojejy's importance in the conservation of biological diversity in Madagascar. It is a centre of endemism in its own right, with at least two reptile, seven amphibian and numerous plant species not known elsewhere (Jenkins 1987). The richness of its flora and herpetofauna was well known before the survey (Humbert 1955, Guillaumet et al. 1975) and it is clear that the diversity of its vegetation supports an avifauna to match.

The two best-known rainforest areas in Madagascar are the Réserve Spéciale d'Analamazaotra and surrounding area (all usually known as Périnet) and the Parc National de Ranomafana. Both are far better studied than Marojejy. More bird species are known from Périnet, although several have not been found there for many years. The avifauna at Ranomafana is quite similar to that at Marojejy, in particular with part of the same distinct community of threatened montane specialists (Rufous-headed Ground-roller, Grey-crowned Greenbul and Madagascar Yellowbrow). However, these areas lack the intact high-altitude forests and scrub for which Marojejy is the finest site in Madagascar (Guillaumet 1984). In a review of key forests for threatened bird species in Africa and related islands (Collar and Stuart 1988), the Marojejy/Andapa area was ranked as equal sixteenth most important forest; employing Collar and Stuart's numerical ranking system (using threatened/near-threatened species as indicators), this survey raises Marojejy/Andapa's status to third in the entire region, and the most important in Madagascar, on current knowledge, for threatened bird species. Although this position is likely to change as further remaining areas are surveyed to similar standard, there can be no doubt that Marojejy has a central role in the conservation of Madgascar's avifauna.

Human pressure on the reserve is great, especially on the species-rich loweraltitude forests close to the boundary. The main threat is slash-and-burn cultivation of hill rice for the large and increasing human population. Villagers often illegally visit the reserve to hunt and collect forest resources. Lemur hunting is very damaging, having probably almost exterminated the diurnal species from the surveyed part of the SW sector, adjacent to the populous Andapa cuvette. Hunting of smaller quarry, fishing, selective logging and collection of plant resources also occur, some in a non-sustainable fashion. Birds seem to be taken largely opportunistically, when people enter the forest for other reasons. No threatened species were seen being captured, but the lack of records of Madagascar Crested Ibis from the degraded SW sector may indicate that it has been hunted out from this area, which had the highest observed densities of lemur traps and other intrusive uses. It is clear that, in contrast to the dangers to diurnal primates (Safford and Duckworth 1990), threats of direct hunting to birds are negligible compared with the insidious piecemeal forest clearance now taking place in Marojejy. 


\section{Acknowledgements}

We particularly enjoy thanking the Direction des Eaux et Forêts, Antananarivo, especially M. Raymond Rakotonindrina and M. Joelina Ratsirarson and the Ministère de l'Enseignement Supérieure, especially Mme Berthe Rakotosamimanana, M. Jeannot Randrianasy and $\mathrm{M}$. Arsene, for allowing this survey to proceed. Advice and help was also gratefully received from: Parc Tsimbazaza, Antananarivo, especially M. Voara Randrianasolo; Direction des Eaux et Forêts, Andapa, especially M. Randrenjasoanarina, M. Christophe Betalata and M. Arsene Simone; M. Roland Christophe, M. Lipo and M. Philibert Ramarojoana (Agents Forestiers, Marojejy); Martin Nicoll, Olivier Langrand and Lalao Rakotondrabesa (WWF-Madagascar) and Lucienne Wilmé; R. M. A. Blommers-Schlösser; Nigel Collar; Peter Colston; Martin Jenkins; Ray Symonds and Don Turner. M. Theore Rakoto and M. Balisy assisted in the field, as did Felix Rakotondraparany and Joanna Durbin.

We express our deepest gratitude to all the organizations, companies and individuals who by their generosity made this survey possible: Air Madagascar, Trinity College, Cambridge, Royal Geographical Society, Barclays Bank plc, Oleg Polunin Memorial Fund, Fauna and Flora Preservation Society (Oryx 100\% Fund), Gilchrist Educational Trust, Loke Wan Tho Memorial Foundation, Peter Scott Trust for Research in Conservation, Simon Whitbread Charitable Trust, Cotton Trust, Downing College, Cambridge, Royal Society of St George, World Wildlife Fund (WWF) US, St Catharine's College, Cambridge, British Ornithologists' Union, British Ecological Society, Percy Sladen Memorial Fund, Cambridge Expeditions Fund, Conder Conservation Trust, Mercers Company Educational Trust, People's Trust for Endangered Species, Robinson Charitable Trust, Emmanuel College, Cambridge, Intervet UK Ltd, 1969 Vinson Charitable Trust, Orlando Oldham Charitable Trust, Pembroke College, Cambridge, Portsmouth Grammar School, Duncan Fraser CBE, Douglas Heath Eves Charitable Trust, Dudley Morgan Charitable Trust, Penrhyn Charitable Trust, RH Technical Industries Ltd, Booker Agriculture International Ltd, Spicers Ltd, Welconstruct Charitable Trust, Gabare Ltd, Culpeper Ltd, Robinsons of Winchester Ltd, C.A.E.C. Howard Ltd, Judith Safford, T. J. Anderson, J. A. Allport, Nitech Ltd, Clyde Canvas Goods and Structures Ltd, Carrington Performance Fabrics, Westcroft MK Ltd, Clothtec Ltd, Swiss Cutlery Ltd, Simmers Biscuits, R. Twining and Co. Ltd, Drinkmaster Ltd, Supreme Plastics, Taunton Leisure, Jessop of Leicester Ltd, A. C. Hughes Ltd, Aquascribe, Cox and Tarry, Direct Foods Ltd and Health + Plus Ltd.

\section{References}

Benson, C. W., Colebrook-Robjent, J. F. R. and Williams, A. (1976-1977) Contribution à l'ornithologie de Madagascar. Oiseau et R.F.O. 46: 103-134, 209-242, 367-386; 47: 41-64, 167-191.

Brown, L. H., Urban, E. K. and Newman, K. (1982) The birds of Africa, 1. London: Academic Press.

Cade, T. (1982) The falcons of the world. London: Collins.

Colebrook-Robjent, J. F. R. (1973) The breeding of the Madagascar Banded Kestrel. Bull. Brit. Orn. Club 93: 108-111.

Collar, N. J. and Stuart, S. N. (1985) Threatened birds of Africa and related islands: the ICBP/ IUCN red data book. Cambridge, U.K.: International Council for Bird Preservation.

Collar, N. J. and Stuart, S. N. (1988) Key forests for threatened birds in Africa. Cambridge, U.K.: International Council for Bird Preservation (Monograph 3).

Cramp, S. and Simmons, K. E. L., eds. (1980) Birds of the western Palearctic, 2. Oxford: Oxford University Press. 
Dee, T. J. (1986) The endemic birds of Madagascar. Cambridge, U.K.: International Council for Bird Preservation.

Duckworth, J. W. (in press) Feeding damage left in bamboo, probably by Aye-ayes Daubentonia madagascariensis. Internatn. J. Primatol.

Evans, M. I. (1991) The Red-tailed Newtonia Newtonia fanovanae in the Ambatovaky reserve, north-east Madagascar. Bird Conserv. Internatn. 1: 47-52.

Goodman, S. M. and Schulenberg, T. S. (1991) The rediscovery of the Red-tailed Newtonia Newtonia fanovanae in south-eastern Madagascar with notes on the natural history of the genus Newtonia. Bird Conserv. Internatn. 1: 33-45.

Green, G. M. and Sussman, R. W. (1990) Deforestation history of the eastern rain forests of Madagascar from satellite images. Science 248: 212-215.

Griveaud, P. (1960) Une mission entomologique au Marojejy. Naturaliste Malgache 12: $43-55$.

Guillaumet, J.-L. (1984) The vegetation: an extraordinary diversity. Pp.27-54 in A. Jolly, P. Oberlé and E. R. Albignac, eds. Key environments: Madagascar. Oxford: Pergamon.

Guillaumet, J.-L., Betsch, J.-M., Blanc, C., Morat, P., Peyrieras, A. and Paulian, R. (1975) Etude des ecosystèmes montagnards dans la région malgache. III Le Marojejy. IV L'Itremo et l'Ibity. Géomorphologie, climatologie, faune et flore (Campagne RCP 225, 1972-73). Bull. Mus. Natn. Hist. Nat. (Paris), sér. 3, 309 (Ecol. Générale) 25: 27-67.

Hawkins, A. F. A., Duckworth, J. W., Evans, M. I. and Safford, R. J. (in prep.) The status, identification and conservation of the Yellow-bellied Sunbird-asity Neodrepanis hypoxantha.

Humbert, H. (1955) Une merveille de la nature à Madagascar. Première exploration botanique du massif de Marojejy, et de ses satellites. Mém. Inst. Sci. Madagascar, Série B, Tome VI.

Jenkins, M. D., ed. (1987) Madagascar, an environmental profile. Gland, Switzerland, and Cambridge, U.K.: International Union for Conservation of Nature and Natural Resources.

King, W. B. (1978-1979) Red data book, 2: Aves. Second edition. Morges, Switzerland: International Union for Conservation of Nature and Natural Resources.

Langrand, O. (1990) Guide to the birds of Madagascar. New Haven and London: Yale University Press.

Langrand, O. and Meyburg, B.-U. (1984) Birds of prey and owls in Madagascar: their distribution, status and conservation. Pp.3-13 in J. M. Mendelsohn and C. W. Sapsford, eds. Proceedings of the Second Symposium on African predatory birds, 22-26 August 1983. Durban: Natal Bird Club.

Lavauden, L. (1937) Supplément. In: A. Milne-Edwards and A. Grandidier, Histoire physique, naturelle et politique de Madagascar, 12. Oiseaux. Paris: Sociétés d'Editions Géographiques, Maritimes et Coloniales.

Ministère de l'Education Nationale à Madagascar (1964) Carte géologique et minière [1:1,000,000 map, three sheets]. Antananarivo.

Nicoll, M. E. and Langrand, O. (1989) Madagascar: revue de la conservation et des aires protégées. Gland, Switzerland: World Wide Fund for Nature.

Quansah, N., ed. (1988) Manongarivo Special Reserve (Madagascar) 1987/88 Expedition Report. London: Madagascar Environmental Research Group.

Rand, A. L. (1932) Mission Franco-Anglo-Américaine à Madagascar. Notes de voyage. Oiseau et R.F.O. 2: 227-282.

Rand, A. L. (1936) The distribution and habits of Madagascar birds. Bull. Amer. Mus. Nat. Hist. 72: 143-499.

Raxworthy, C. J. and Colston, P. R. (1992) Conclusive evidence for the continuing existence of the Madagascar Serpent-eagle. Bull. Brit. Orn. Club 112: 108-111.

Safford, R. J. and Duckworth, J. W., eds. (1990) A wildlife survey of Marojejy nature reserve, 
Madagascar. Cambridge, U.K.: International Council for Bird Preservation (Study Report 40).

Safford, R. J., Duckworth, J. W., Evans, M. I., Hawkins, A. F. A., Sheldon, B. C. and Wilkinson, R. J. (in prep.) The bird communities of Marojejy Strict Nature Reserve.

Sheldon, B. C. and Duckworth, J. W. (1990) The rediscovery of the Madagascar Serpenteagle Eutriorchis astur. Bull. Brit. Orn. Club 110: 126-130.

Thiollay, J. M. (1989) Area requirements for the conservation of rain forest raptors and gamebirds in French Guiana. Conserv. Biol. 3: 128-137.

Thompson, P. M. and Evans, M. I. (1992) The threatened birds of Ambatovaky Special Reserve, Madagascar. Bird Consero. Internatn. 2 (this issue).

Turner, D. A. (1984) The ground-rollers of Madagascar. Proc. V Pan-Afr. Orn. Congr.: 553-557.

White, F. (1983) The vegetation of Africa. A descriptive memoir to accompany the Unescol AETFAT/UNSO vegetation map of Africa. Paris: Unesco.

Whitmore, T. C. (1984) Tropical rain forests of the Far East. Second edition. Oxford: Clarendon Press.

MICHAEL EVANS

Montrose, Llanddeiniol, Llanrhystud, Dyfed SY23 $5 A N$, U.K.

WILL DUCKWORTH

Dept of Zoology, Downing Street, Cambridge CB2 $3 E J$, U.K.

FRANK HAWKINS

10 Lodway Gardens, Pill, Bristol BSzo oDL, U.K.

ROGER SAFFORD

16 Berwyn Road, Richmond, Surrey TW1o 5BS, U.K.

BEN SHELDON

Department of Animal and Plant Sciences, The University, Western Bank, Sheffield Sto 2TN, U.K.

ROGER WILKINSON

27 Blackbrook Park Avenue, Fareham, Hampshire PO15 5 JN, U.K. 